\title{
IMPACTS OF TYPHOON NONA IN THE COASTAL AREAS OF BIRI- LAROSA
}

\author{
Elbert Yruma ${ }^{1} \boldsymbol{\mathbb { U }}$ iD , Myrna Nicol Ogoc, PhD ${ }^{2}$ \\ ${ }^{1}$ BS Environmental Science, College of Science, University of Eastern Philippines \\ 2 College of Science, University of Eastern Philippines
}

DOI: https://doi.org/10.29121/granthaalayah.v8.i10.2020.1706

Article Type: Research Article

Article Citation: Elbert Yruma, and Myrna Nicol Ogoc, PhD. (2020). IMPACTS OF TYPHOON NONA IN THE COASTAL AREAS OF BIRILAROSA. International Journal of Research -GRANTHAALAYAH, 8(10), 187-192. https://doi.org/10.29121/granthaa layah.v8.i10.2020.1706

Received Date: 23 September 2020

Accepted Date: 30 October 2020

Keywords:

Impacts

Typhoon

Coastal Areas

Biri-Larosa

\section{ABSTRACT}

A descriptive type of study on the impacts of typhoon Nona was conducted from August 2016 to January 2017 in the selected coastal barangays of Biri, Lavezares, Rosario, and San Jose, (Biri-LaRoSa) which form part of the Biri-LaRoSa seascape and landscape of the province of Northern Samar. It focused on the impacts of the typhoon to the coastal environment and its socio-economic effect.

Actual field sampling was done for the quantitative assessment of the coastal ecosystems. Participatory Resource Appraisal (PRA) tools were used for the qualitative assessment.

Biri area has a total of $23.5 \%$ partially damaged trees and $9.4 \%$ totally damaged trees in the mangrove ecosystem; $51.7 \%$ damage to the seagrass beds; and $79.1 \%$ damage to the corals.

Lavezares area has a total of 32.5\% partially damaged trees and 9.5\% totally damaged trees in the mangrove ecosystem; $47.9 \%$ damage to the seagrass beds; and $76.5 \%$ damage to the corals.

Rosario area has a total of 33\% partially damaged trees and 5.8\% totally damaged trees in the mangrove ecosystem; $47.6 \%$ damage to the seagrass beds; and $36.1 \%$ damage to the corals.

San Jose area has a total of $39.6 \%$ partially damaged trees and $7.6 \%$ totally damaged trees in the mangrove ecosystem; $48 \%$ damage to the seagrass beds; and $56.8 \%$ damage to the corals.

Typhoon Nona greatly affected the ecosystems in the sampling sites and in turn affected the socio-economic conditions of 'the locals, especially those who are dependent on the coastal resources both for food and income. Both results of the PRA and actual field assessment support this claim.

\section{INTRODUCTION}

The Biri-Larosa Protected Landscape/Seascape (BLPLS) was proclaimed as a protected area under the category of Protected Landscape/Seascape by virtue of Presidential Proclamation No. 291 on April 23, 2000 and RA 11038 (E-NIPAS) on account of its famous geological wonders known as "Rock Formations", tropical mangroves and excellent display of benthic life forms. Situated northernmost of the Province of Northern Samar, BLPLS, spanning 33,492 hectares, is the coastal areas of Lavezares, Rosario, San Jose and embracing the Biri Group of Islands and its surrounding reefs.

(C) 2020 The Author(s). This is an open access article distributed under the terms of the Creative Commons Attribution License, which permits unrestricted use, distribution, and reproduction in any medium, provided the original author and source are credited. 
It harbors interesting animals such as insects, bats and birds that describes the site as one of the Key Biodiversity Sites (KBA 129). There is a complete ecosystem, wherein two of the coral species are considered to be the trigger species of the Protected Area as listed by Conservation International (www.conservation.org): Acropora puertogalerae and Goneopora cellulosa, hence this study.

Tropical storms (hurricanes, cyclones, and typhoons) are extremely destructive phenomena. They cause considerable damage to life and property around the globe due to the effects of strong winds, heavy rains, and tidal surges (Glantz, 2003).

The Philippines is highly vulnerable to the impacts of natural disasters. Located within the Pacific Ring of Fire and the typhoon belt on the North Pacific Basin, it is prone to earthquakes, volcanic eruptions, tsunamis and typhoons.

A typhoon is a mature tropical cyclone that develops in the western part of the North Pacific Ocean between $180^{\circ}$ and $100^{\circ} \mathrm{E}$. This region is referred to as the Northwestern Pacific Basin, and is the most active tropical cyclone basin on Earth, accounting for almost one third of the world's annual tropical cyclones.

Typhoon Melor, known in the Philippines as Typhoon Nona, was a strong tropical cyclone that struck the Philippines in December 2015. Melor killed 42 people and caused P6.45 billion (US\$136.4 million) in damage.

The typhoon started on December 7 as a low-pressure area $120 \mathrm{~km}(75 \mathrm{mi})$ of Chuuk. Soon, it turned into a tropical depression on December 9, and into a tropical storm south of Yap, and named Melor.

An estimated cost of damage to infrastructure and agriculture amounting to P935,192,943.51 were reported in Regions IV-B.

The purpose of this study is to determine the level of damages caused by typhoon Nona to the coastal areas of Biri-LAROSA, Northern Samar, being proclaimed as a protected landscape and seascape under Batas Pambansa 291 of 2000.

\section{OBJECTIVES OF THE STUDY}

\subsection{SPECIFICALLY, THIS STUDY}

1) determined the environmental impacts of typhoon Nona in coastal areas of Biri-LAROSA. Northern Samar in terms of the level of visible damages caused by the typhoon particularly in the mangrove ecosystem, sea grass beds and coral reef communities;

2) determined the socio-economic impacts of typhoon Nona in the coastal areas of Biri-LAROSA Northern Samar; and,

3) determined the interventions made after the typhoon.

\section{METHODS AND PROCEDURES}

\subsection{PARTICIPATORY RESOURCE ASSESSMENT (PRA)}

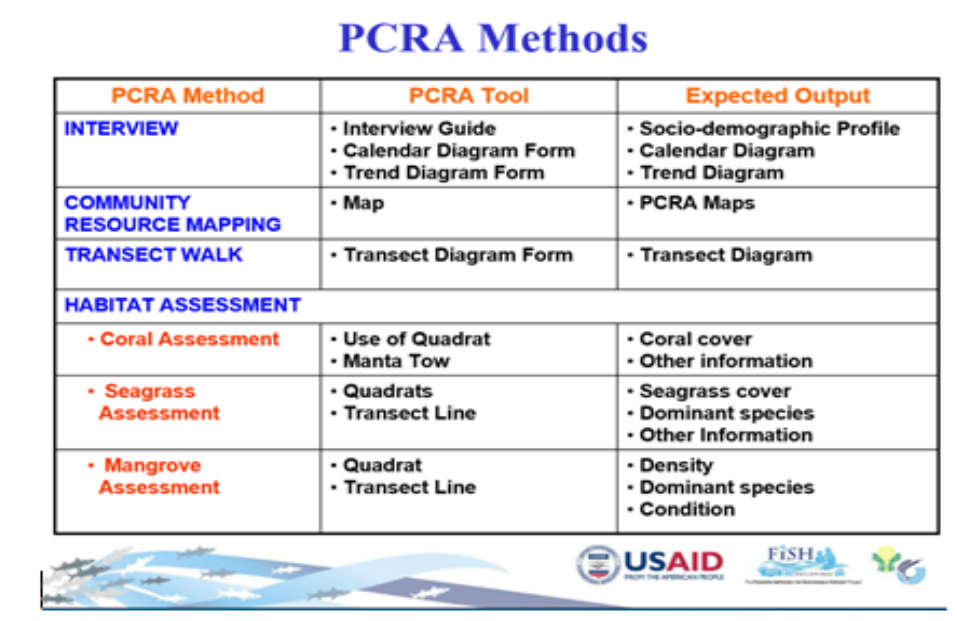




\subsection{ACTUAL FIELD ASSESSMENT}

\section{Mangrove Habitat Assessment}

Line transects plot sampling and basal diameter measurement of mangrove trees. Three sampling stations were established in the area. For each station, transect lines range 100 meters was laid perpendicular to the shoreline. Within, the transect line 10x10 m plots for the sampling of mangrove trees (mangrove with a basal stem diameter of $4 \mathrm{~cm}$ and higher with more than $1 \mathrm{~m}$ height) were set up with an interval of twenty meters in every plot. In every station, five 10x10 m plots were laid. The mangrove inside the plot was identified and counted, the diameter at breast height $(\mathrm{dbh})$ in $\mathrm{cm}$, basal area in meter and density was measured

\section{Sea Grass Beds Assessment}

The Transect-Quadrat Method is used to estimate seagrass cover and relative abundance of the different seagrass species in a given area.

1) A $50 \mathrm{~m}$ transects along the seagrass area parallel to the shoreline were laid. Transects was set at 50 meters apart to represent the nearshore and middle portion of the seagrass meadow. Coordinates of the beginning and end of each transect were recorded.

2) Quadrats at $5 \mathrm{~m}$ interval, starting at point 5 was laid. Each transect have a total of 10 readings or recordings. In setting down the quadrat, always place the quadrats on the right side of the transect line and walk on the left side to avoid trampling on the seagrass.

3) Inside each quadrat, seagrass species found and the percent cover of each species was recorded.

4) For the seagrass species identification and percent cover estimation, guide for identification and estimation was used

\section{Coral Reefs Assessment}

The Point Intercept Technique (PIT) was used in the asessment of the coral reef area by providing estimates of the relative abundance of living and non- living things;

The indicators for PIT are percent live hard coral cover per genus and lifeforms, percent dead coral cover, soft coral, macro-algae, sand, and rocks.

PIT is best done by scuba diving; however, snorkel survey was adopted in this assessment shallow areas (Uychiaoco et al 2001). Methods for assessing and monitoring coral reef biodiversity

\section{SUMMARY DISCUSSION OF RESULTS}

This study determined the socio-economic and environmental impacts of typhoon Nona in the selected coastal areas of Biri-LAROSA.

The descriptive research was used in this study. Participatory Coastal Resource Appraisal was used to determine qualitatively the socio-economic and the environmental impacts of the typhoon. Actual field assessment was also conducted in order to validate the veracity of the data gathered from the PRA.

\section{Brgy. San Pedro, Biri, N. Samar}

Participatory Resource Assessment (PRA)

The participants estimated about $60 \%$ damage to the mangrove; $50 \%$ sea grass; $20 \%$ to the corals. These damages affected the fishermen' income due to the decrease in fish catch caused by turbid water and destroyed habitat.

\section{Actual Field Assessment}

\section{Mangrove Habitat Assessment}

In the 3 transects, a total number of 200 trees (67.1\%) were counted as not affected. A total number of 28 trees $(9.4 \%)$ were counted as totally damaged. A total number of 70 trees $(23.5 \%)$ were counted as partially damaged.

\section{Sea Grass Beds Assessment}

A. total of $51.7 \%$ damage was computed. Most of the damages were caused by being washed out due to strong wind and currents. Corals have also been removed from their substrate then carried to the sea grass beds and the shore. Sand has also covered the sea grass beds, and caused death to it. 


\section{Coral Reefs Assessment}

There were $79.1 \%$ computed damage to the corals, and $20.9 \%$ were not affected. Most of the damages were cut branches in coral branching, and removed boulders of coral massive.

\section{Brgy. Marvilla, Lavezares, N. Samar}

\section{PRA}

The condition of the mangrove, sea grass, and corals was good before the typhoon. The participants estimated about $60 \%$ damage to the mangrove; $90 \%$ sea grass; $90 \%$ to the corals. These damages affected the fishermen' income due to the decrease in fish catch caused by turbid water and destroyed habitat.

\section{Actual Field Assessment}

\section{Mangrove Habitat Assessment}

In the 3 transects, a total number of 219 trees (58\%) were counted as not affected. A total number of 36 trees $(9.5 \%)$ were counted as totally damaged. A total number of 123 trees (32.5\%) were counted as partially damaged.

\section{Sea Grass Beds Assessment}

A total of $47.9 \%$ damage was computed. Most of the damages were caused by being washed out due to strong wind and currents. Corals have also been removed from their substrate then carried to the seagrass beds. Sand has also covered the seagrass beds, and caused death to it.

\section{Coral Reefs Assessment}

There were $23.5 \%$ computed damage to the corals, and $76.5 \%$ were not affected. Most of the damages were cut branches in coral branching, and removed boulders of coral massive.

\section{Brgy. Buenavista, Rosario, N. Samar}

\section{Participatory Resource Assessment (PRA)}

The participants estimated about $50 \%$ damage to the mangrove; $99 \%$ to seagrass; $50 \%$ to the corals. These damages affected the fishermen' income due to the decrease in fish catch caused by turbid water and destroyed habitat.

\section{Actual Field Assessment}

\section{Mangrove Habitat Assessment}

In the 3 transects, a total number of 211 trees (61.2\%) were counted as not affected. A total number of 20 trees $(5.8 \%)$ were counted as totally damaged. A total number of 114 trees (33\%) were counted as partially damaged.

\section{Sea Grass Beds Assessment}

A total of $47.6 \%$ damage was computed. Most of the damages were caused by being washed out due to strong wind and currents. Corals have also been removed from their substrate then carried to the sea grass beds. Sand have also covered the sea grass beds, and caused death to it.

\section{Coral Reefs Assessment}

There were $36.1 \%$ computed damage to the corals, and 63.9\% were not affected. Most of the damages were cut branches in coral branching, and removed boulders of coral massive.

\section{Brgy. Dao, San Jose, N. Samar}

\section{Participatory Resource Assessment (PRA)}

The condition of the mangrove, sea grass, and corals was good before the typhoon.

The participants estimated about $50 \%$ damage to the mangrove; $30 \%$ sea grass; $60 \%$ to the corals. These damages affected the fishermen' income due to the decrease in fish catch caused by turbid water and destroyed habitat.

\section{Actual Field Assessment}

\section{Mangrove Habitat Assessment}

In the 3 transects, a total number of 160 trees (52.8\%) were counted as not affected. A total number of 23 trees (7.6\%) were counted as totally damaged. A total number of 120 trees (39.6\%) were counted as partially damaged.

\section{Sea Grass Beds Assessment}

A total of $48 \%$ damage was computed. Most of the damages were caused by being washed out due to strong wind and currents. Corals have also been removed from their substrate then carried to the sea grass beds. Sand has also covered the sea grass beds, and caused death to it.

\section{Coral Reefs Assessment}

There were $56.8 \%$ computed damage to the corals, and $43.2 \%$ were not affected. Most of the damages were cut branches in coral branching, and removed boulders of coral massive. 


\section{Socio-economic Impacts}

The results of the FGD about the socio-economic impacts of the typhoon in the 4 barangays were similar. The participants especially those who are dependent on the coastal resources say that the typhoon caused negative impact on their daily income. They say that the water stayed turbid for how many weeks resulting to decrease in fish catch to the point that there's no fish to catch at all.

This considerable decrease in their income and food source resulted to starvation since the locals got no other side-lines in order to obtain money. The locals got nothing to do but to wait for the reliefs. Their children's academic performance was also affected because instead of going to school the child would just help their parents to gain income.

The typhoon also caused trauma to the locals not only because of its capability to destroy houses but also because of the decrease in income that can lead to crisis.

\section{CONCLUSION}

Typhoon. Nona greatly' affected the ecosystems in the sampling sites and in turn affected the economic activities of the locals especially those who are dependent on the coastal resources both for food and income. Both from the PRA and Actual field assessment support this claim. The interventions after the typhoon were the restoration of the ecosystems in the sampling site.

\section{RECOMMENDATIONS}

1) Strictly prohibit the cutting of mangroves and the destruction of corals to protect the locals from typhoon induced damage since the two ecosystems serve as natural buffers of wind and waves.

2) Replant the mangroves on a suitable habitat for good growth.

3) Strict implementation of National Integrated Protected Area System Act, NIPAS Law for the conservation and protection of Protected areas;

4) Massive Information and Education campaign at the local-barangay levels on the importance of mangrove, corals and other ecosystem as man's life support system.

\section{SOURCES OF FUNDING}

This research received no specific grant from any funding agency in the public, commercial, or not-for-profit sectors.

\section{CONFLICT OF INTEREST}

The author have declared that no competing interests exist.

\section{ACKNOWLEDGMENT}

None.

\section{REFERENCES}

\section{Book/Booklet}

[1] Glantz, Michael H. 2003 Climate Affairs, Aprimer; pP50

[2] English, at al. 1994. Surve Manual for "Tro-ical Marine Resources. ASEAN Australian Marine Science ProjeCt Journals/Manuals

[3] A Manual on Floods and Storms Preparedness an Mitigation for Communities, Care International In Vietnam; pp. 9

[4] Israel. Danilo c. 2012 "Typhoons, f loods, and droughtszregional occurrence and value of damages." Polic Notes 
[5] Ed Chaves, et al., 2003 "Manual for Participatory Development Planning and Budgeting."Institute of Politics and Governance

[6] 2015 "More intense typhoons: What does a changing climatemean for food security in the Philippines?" PHILIPPINES; pp. 9-10

[7] Chughtai, Shaheen 2013 "The response so far and vitallessons for the Philippines recovery." TYPHOON HAIYAN; PP. 5-6

\section{Unpublished Works}

[8] BradecinaRaul G., Plutomeo M. Nieves, Ma. JosefaPelea, TeruyukiShinbo and Yoshinori Morooka 2012. "Socioeconomic, Ecological and Institutional Impacts of Super Typhoon Reming: On a community-based Mangrove Rehabilitation ProjeCt 1n Malinao, Albay, Philippines".

\section{Case Study}

[9] 2015, Typhoon Yolanda Ongoing Recovery, Recove- ry May Framework E.Dictionary Merriam-Webster, Incorporated.

\section{Other Sources}

[10] Cavallor E., S. Galiani, I. Noy and J. Pantano (2010), 'Catastrophic Natural Disasters and Economic Growth', IDB Working Paper Series No. IDB-WP-183, InterAmerican Development Bank, $27 \quad$., http://idbdocs.iadb.org/wsdocs/getdocument.aspx?docnum =35220118 (accessed February 20, 2012).

[11] Toya, H. and M. Skidmore (2005), 'Economic Development and the Impacts of NaturalDisasters', WOrking Paper 05 -04, University of Wisconsin Whitewater Department of Economics, Whitewater, Wisconsin, U.S.A., 13 p., httB://su2.kathimerini.gr/xtra/media/files/fin/nat_ski dmore.pdf (accessed February 20, 2012).

[12] Loayza, N., E. Olaberria, J. Rigolini and L. Christiaensen, (2009), 'Natural Disasters and Growth Going beyond the Averages', Policy Research Working Paper4980, The World Bank East Asia and Pacific Social Protection Unit \& Development Research Group, 40 p., htto://ofdrr.oro/docs/WPS4980.odf (accessed February 20, 2012).

[13] Sivakumar, bL 'V. K. (2005), 'Impacts of Natural Disasters in Agriculture, Rangeland and Forestry: An Overview', in, M. V. K. Sivakumar, R "P. Motha and H. P. Das (Eds.) Natural Disasters and Extreme Events in

Agriculture. Springer Hiderberg Berlin, New York, pp. 122, htt ://books. 00 le.com.oh/books?id=souWde1908C $\&=$ RA1\&l =PAl\&d-=Im acts+of+Natural+Disasters+in+Aoric ulture,+Raneand+and+Forestry:+An+Overview\&source $=$ bl $\&$ ots=255Au3ijH\&sig=CNxQJ2x4291101e8zjvaOthVQ\&hl=tl\&33'X591'P250Tn1Cqu6iAeSserCg\&ved=OCBwQ 6AEwAA\#v=onePage\&Q'ImPacts\%200f\%20Natura1\%ZODisasters\%201n\%ZOAgriculture\%2C820Rangela nd\%ZOand\%20Forestry\%3A\%20An\%200verv iew\&f-false(accessed February 20, 2012).

[14] National Research Council (1999), 'Appendix A: Environmental Impacts of Natural Disasters.' In The Impacts of Natural Disasters: A Framework for Loss Estimation, Washington, DC: The National Academies Press, 1999, http://www.nap.edu/openbook.php?record_id=6425\&page=5 5(accessed February 1, 2012).

\section{ONLINE SOURCES}

[1] https://en.wiki-edia.oro/wiki/T1-hoon htt-s://en.wiki-edia.oro/wiki/T1-hoon Melor

[2] https://en.wiki edia.oro/wiki/Biri Larosa Protected Landsca Ee/Seascage

[3] https://en.wiki-edia.oro/wiki/Northern Samar

[4] https://www.oov.oh/2015/12/18/reoort-on-effects-of-t 'ohoonnona-as-of-800-a-m-december-18-2015/

[5] https://enviroliterac. oro/water/coastal-areas/

[6] https://www.ehow.com/facts 7675093 coastal-ecos stems.htm1

[7] Diversity and species composition of mangroves in Barangay Imelda, Dinagat Island, Philippines Lutess P. Cañizares, Romell A. Seronay AACL Bioflux, 2016, Volume 9, Issue 3. http://www.bioflux.com.ro/aacl 